http://dx.doi.org/10.11646/zootaxa.3925.2.2

http://zoobank.org/urn:lsid:zoobank.org:pub:1C440345-E190-41BF-977B-DCA5DFE705A9

\title{
Revision of the Palaearctic and Oriental species of the genus Naarda Walker, 1866 (Lepidoptera: Erebidae, Hypeninae). Part 5. Description of 13 new species from Asia
}

\author{
BALÁZS TÓTH ${ }^{1}$ \& LÁSZLÓ RONKAY \\ Collection Lepidoptera, Department of Zoology, Hungarian Natural History Museum, Baross utca 13, H-1088 Budapest, Hungary \\ ${ }^{1}$ Corresponding author. E-mail: balazs0toth@gmail.com
}

\begin{abstract}
Descriptions of 13 new Naarda species, N. cingulata (Thailand), N. imitata (Cambodia), N. hallasana (Korea), N. calligrapha (India, Burma and Indonesia: Buru Island), N. felinopsis (Vietnam), N. furcipalpa (Brunei), N. uthanti (Burma), N. capreola (Cambodia), N. leptosigna (Sri Lanka), N. nigrissima (Cambodia, Thailand and Taiwan), N. bicolora (Cambodia), $N$. gigaloba (Sri Lanka) and N. numismata (India) spp. n. are given. With 50 figures.
\end{abstract}

Key words: Naarda, Hypeninae, new species, Asia, description, genitalia, labial palps

\section{Introduction}

With the publication of this part the number of Naarda species described by the authors as new for the science rises to 63 and the total number of Oriental and Palaearctic taxa exceeds the 90. In contrast to the previous four parts (Tóth \& Ronkay, 2014a; in press: b; 2015a and b), which deal with more or less distinct and compact evolutionary lineages, this paper contains the descriptions of a dozen of species from different internal groups. This article presents largely the results of the first author's research in The Natural History Museum, London, and the results of the study of hitherto unidentified material of the Hungarian Natural History Museum, Budapest.

Literature sources include, besides the recent works of the authors, practically only the original descriptions of the species given by Walker (1858, 1859, 1866), Hampson (1891, 1893, 1902, 1912), Staudinger (1892), Wileman (1915), Strand (1920), Prout (1928), de Joannis (1929), Sugi (1982), Holloway (2008) and Deng \& Han (2011).

According to our plans, this is the last part containing only descriptions; the next item will enumerate all Asian species and establish the infrageneric systematics of the group.

\section{Material and methods}

The method of preparing permanent genitalia slides, the genitalia terminology and the structure of species descriptions are the same as in the first part of this series. We continue the practice of designating the least worn male specimen as holotype in each description.

Abbreviations: BMNH-The Natural History Museum, London (formerly the British Museum of Natural History); HNHM-Hungarian Natural History Museum, Budapest; HSS-Heterocera Sumatrana Society, Göttingen; MF — The private collection of the late Michael Fibiger (currently hosted at ZMUC); MFN-Berlin Natural History Museum-Museum für Naturkunde, Berlin; OUMNH-Oxford University Museum of Natural History; SDEI-German Entomological Institute-Senckenberg Deutsches Entomologisches Institut, Müncheberg; TFRI - Taiwan Forestry Research Institute, Taipei, Taiwan; ZFMK-Alexander Koenig Museum, Bonn-Zoologisches Forschungsinstitut und Museum Alexander Koenig; ZMUC_Zoological Museum of the University of Copenhagen; ZSM-Zoological State Collection, Munich—Zoologische Staatssammlung, München. 

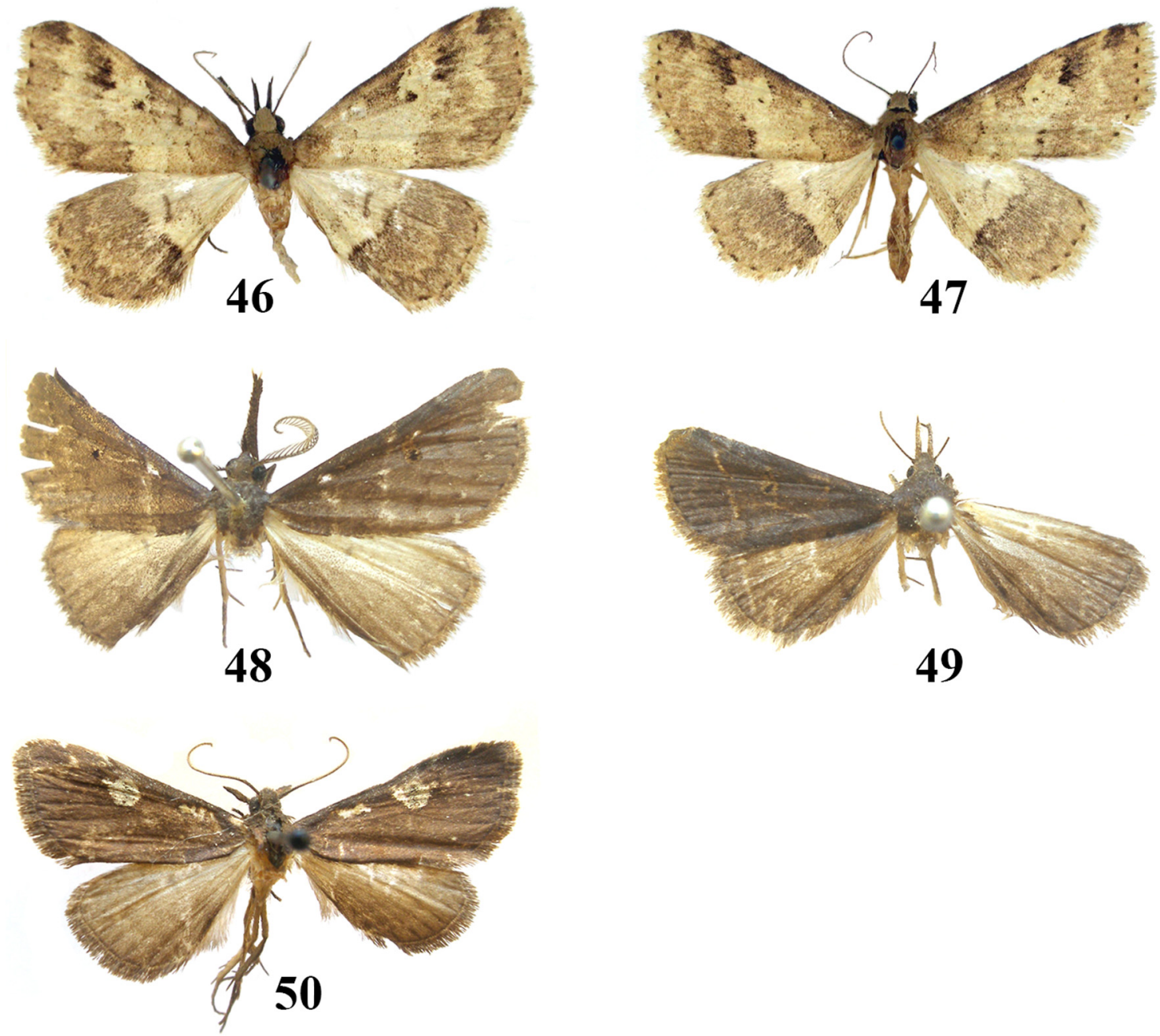

PLATE 7. Adults of Naarda species.

Figure 46: Naarda sp. near $N$. lancanga, male Figure 47: $N$. sp. near $N$. lancanga, female Figure 48: $N$. gigaloba sp. n. male, holotype Figure 49: $N$. gigaloba $\mathbf{s p .}$. female, paratype Figure 50: $N$. numismata sp. n. male, holotype

Figures 2-8, 10-16, 18, 20-21 and 23-25 were prepared by János Babics; 38-39 by Alberto Zilli; remaining by the authors. Figures are not to scale.

\section{References}

Deng, G. \& Han, H.-L. (2011) A new species of Naarda from Southwest China (Lepidoptera, Noctuidae, Hypeninae). Tinea, 21 (5), 256-258.

Hampson, G.F. (1891) Illustrations of typical specimens of Lepidoptera Heterocera in the Collection of the British Museum VIII: The Lepidoptera Heterocera of the Nilgiri District. Taylor \& Francis, London, $144+4$ pp., 8 pls.

Hampson, G.F. (1893) Illustrations of typical specimens of Lepidoptera Heterocera in the Collection of the British Museum IX: The Macrolepidoptera Heterocera of Ceylon. Taylor \& Francis, London, $182+5$ pp., 20 pls.

Hampson G.F. (1902) The moths of India. Supplementary paper to the volumes in 'The Fauna of British India' Series II, Part VI. Journal of the Bombay Natural History Society, 14, 197-219.

Hampson, G.F. (1912) The moths of India. Supplementary paper to the volumes in 'The Fauna of British India' Series IV, Part V. Journal of the Bombay Natural History Society, 21, 1222-1272, pl. 1. 
Holloway, J.D. (2008) The moths of Borneo: family Noctuidae, subfamilies Rivulinae, Phytometrinae, Herminiinae, Hypeninae, Hypenodinae. Malayan Nature Journal, 60 (1-4), 1-268.

de Joannis, J. (1929) Lépidoptères Heterocères du Tonkin. Annales de la Société Entomologique de France, 98, 361-557, pls. $1-3$.

Kononenko, V.S. \& Han, H.-L. (2007) Atlas genitalia of the Noctuidae in Korea (Lepidoptera). In: Park, K.T. (Ed.), Insects of Korea 11. Center for Insect Systematics, Chuncheon, 460 pp. [Korea]

Prout, L.B. (1928) Noctuid moths from some of the mountains of Sarawak, The Sarawak Museum Journal, 3, 461-503, pls. $1-2$.

Staudinger, O. (1892) Die Macrolepidopteren des Amurgebiets I. Theil. Rhopalocera, Sphinges, Bombyces, Noctuae. In: Romanoff, N.M. (Ed.), Mémoirs sur les Lépidoptères 6. Imprimerie de M. M. Stassuléwitch, St. Petersburg, pp. 1-575 pp, pls. $1-10$.

Strand, E. (1920) H. Sauter's Formosa-Ausbeite: Noctuidae II., nebst Nachtrage zu den Familien Arctiidae, Lymantriidae, Notodontidae, Geometridae, Thyrididae, Pyralidae, Tortricidae, Gelechiidae und Oecophoridae. Archiv für Naturgeschichte, 84 A (12), 102-197.

Sugi, Sh. (1982) Noctuidae. In: Inoue, H., Sugi, Sh., Kuroko, H., Moriuti, Sh. \& Kawabe, A. (Eds.), Moths of Japan I-II. Kodansha Co., Tokyo, pp. 1-966 + 1-402.

Tóth, B. \& Ronkay, L. (2014a) Revision of the Palaearctic and Oriental species of the genus Naarda Walker, 1866 (Lepidoptera: Erebidae, Hypeninae). Part 3. Description of three new species from Asia. Nota Lepidopterologica, 37 (1), 9-18. http://dx.doi.org/10.3897/nl.37.7957

Tóth, B. \& Ronkay, L. (2014b) Revision of the Palaearctic and Oriental species of the genus Naarda Walker, 1866 (Lepidoptera: Erebidae, Hypeninae). Part 1. Taxonomic notes and description of 28 new species from Asia. Oriental Insects, 48 (1-2), 1-49. http://dx.doi.org/10.1080/00305316.2014.959790

Tóth, B. \& Ronkay, L. (2015a) Revision of the Palaearctic and Oriental species of the genus Naarda Walker, 1866 (Lepidoptera: Erebidae, Hypeninae). Part 2. Description of ten new species from Asia. Acta Zoologica Academiae Scientiarum Hungaricae. [in press]

Tóth, B. \& Ronkay, L. (2015b) Revision of the Palaearctic and Oriental species of the genus Naarda Walker, 1866 (Lepidoptera: Erebidae, Hypeninae). Part 4. Description of nine new species from Asia. Journal of Asia-Pacific Entomology. [in press] http://dx.doi.org/10.1016/j.aspen.2015.02.001

Walker, F. (1858) List of specimens of the lepidopterous insects of the Collection of the British Museum 16. Edward Newman, London, $253 \mathrm{pp}$.

Walker, F. (1859) List of specimens of the lepidopterous insects of the Collection of the British Museum 19. Edward Newman, London, $238 \mathrm{pp}$.

Walker, F. (1866) List of specimens of the lepidopterous insects of the Collection of the British Museum 35. Edward Newman, London, $506 \mathrm{pp}$.

Wileman, A.E. (1915) New species of Noctuidae from Formosa, The Entomologist, 48, 191-196. 